\title{
COMPETITIVENESS OF BULGARIAN ORGANIC PRODUCTS
}

\author{
G. Aleksiev* \\ Faculty of Economics, Trakia University, Stara Zagora, Bulgaria
}

\begin{abstract}
The production of organic products in Bulgaria is constantly growing and the role of this type of production in the development of the agricultural sector cannot be ignored. Bulgarian bio-products have an export orientation and a very small part are traded in the domestic market, which also determines the importance of their competitiveness for the future development of the sector. The purpose of this study is to analyze the competitive position of Bulgarian bio-products. In order to achieve its goal, the research has to solve the following tasks: to analyze the trade with organic products in Bulgaria; to evaluate the potential for development of trade in bio-products in the internal market; to evaluate the competitiveness of Bulgarian organic products.
\end{abstract}

Key words: production, trade, sustainability

\section{INTRODUCTION}

By 2015, the processing sector for organic agricultural products is underdeveloped and this is one of the reasons for the low levels of local organic food supply. The change in this trend was observed at the end of 2015 and the beginning of 2016, when the number of processors increased sharply, mainly due to EU-subsidized investments and increased consumer demand. The main processed products are yogurt, cheese, honey, bread, wine, herbs and tea.

Organic food sales were estimated in 2015 at BGN 30 million (US \$ 17 million), up 7\% from 2014. The growth over the last 5 years (2015 compared to 2010) was impressive $73 \%$. The sales estimate for 2016 is about BGN 31.6 million (USD 17.5 million) or $5.3 \%$ more than in 2015 and may reach BGN 33.3 million (USD 18.5 million). E.) in 2017 (final data for 2017 are not yet available) Estimated levels of sales of organic products in Bulgaria in 2020 amounting to over 39 million. This would represent an increase of 30\% (20152020).

\section{LOCAL ORGANIC MARKET}

Most estimates of the size of the organic food

*Correspondence to: Georgi Aleksiev, Faculty of Economics, Trakia University, Stara Zagora 6000, Bulgaria,georgi.alexiev@gmail.com market place it at $1 \%$ of the total food market, although official data fail to support this claim due to the lack of adequate reporting of sales of organic products on the national market. Sales of organic baby food accounted for the largest share of organic product sales - 36\% in 2015 (Table 2). Trade levels increased and in 2015 were $63 \%$ higher than in 2010 and $7 \%$ higher than in 2014. The presence of wellestablished manufacturers in this segment with reliable and high-quality products maintained high levels of demand. The market leader in this category maintains organic baby food prices that are only slightly higher than conventional equivalents, and this strategy is attracting an increasing number of consumers. The milk and milk products category is the second after baby foods with an $18 \%$ share of total organic food sales in 2015. In 2015, these sales were $10 \%$ higher than in 2014 and 54\% higher than in 2014. 2006

In 2015, the best-selling organic products are chilled processed meat and seafood with a growth of $24 \%$. All of these products are imported and represent only $1 \%$ of total organic product sales. Bulgarian organic food lovers have the greatest preference for a vegetarian diet and this is the reason for the slow development of this product category (Euromonitor, 2016). 
Table 1. Distribution of Organic Packaged Food By Format 2013-2015

\begin{tabular}{|l|l|l|l|}
\hline & $\mathbf{2 0 1 3}$ & $\mathbf{2 0 1 4}$ & $\mathbf{2 0 1 5}$ \\
\hline Grocery Retailers & $98.80 \%$ & $99.00 \%$ & $99.00 \%$ \\
\hline Modern Grocery Retailers & $57.30 \%$ & $58.60 \%$ & $61.40 \%$ \\
\hline Convenience Stores & $4.60 \%$ & $4.40 \%$ & $4.40 \%$ \\
\hline Discounters & $27.30 \%$ & $28.30 \%$ & $28.60 \%$ \\
\hline Hypermarkets & $0.80 \%$ & $0.80 \%$ & $1.00 \%$ \\
\hline Supermarkets & $23.00 \%$ & $23.60 \%$ & $26.00 \%$ \\
\hline Traditional Grocery Retailers & & & \\
\hline Independent Small Grocers & $25.20 \%$ & $23.90 \%$ & $20.90 \%$ \\
\hline Other Grocery Retailers & $16.3 \%$ & $16.5 \%$ & $16.8 \%$ \\
\hline Internet Retailing & $0.2 \%$ & $0.2 \%$ & $0.2 \%$ \\
\hline Total & $100.0 \%$ & $100.0 \%$ & $100.0 \%$ \\
\hline
\end{tabular}

Source: Euromonitor

Organic beverages are an emerging category of organic products. Their prices are high, often exceeding their conventional equivalents by $300-500 \%$. Organic coffee, cocoa and energy drinks are the most common on the market. Consumers are not very familiar with organic drinks. They are often looking for healthier lifestyles and prefer to buy freshly squeezed juices with reduced sugar content and low calorie or water minerals, and therefore sales are unlikely to develop quickly in the future without further marketing efforts.

Rapid sales are expected for organic dairy, bee, wine and pasta sales. These products are sourced from both local manufacturers and importers, allowing for greater competition, diversity, brand differentiation and promotion. The trend of expanding purchases of fresh fruits and vegetables will continue to develop.

Table 2. Sales of Organic Packaged Foods by Category 2010-2015 (mil. \$US)

\begin{tabular}{|l|l|l|l|l|l|l|}
\hline & $\mathbf{2 0 1 1}$ & $\mathbf{2 0 1 2}$ & $\mathbf{2 0 1 2}$ & $\mathbf{2 0 1 3}$ & $\mathbf{2 0 1 4}$ & $\mathbf{2 0 1 5}$ \\
\hline Organic Baby Food & 3.7 & 3.8 & 4.9 & 5.3 & 5.6 & 6.1 \\
\hline Organic Bakery Products & 1.3 & 1.4 & 1.6 & 2 & 1.9 & 2.1 \\
\hline Organic Biscuits, Snack Bars, Cereals & 0.4 & 0.7 & 0.8 & 0.8 & 0.9 & 0.9 \\
\hline Organic Dairy & 1.9 & 2 & 2.3 & 2.5 & 2.7 & 3 \\
\hline $\begin{array}{l}\text { Organic Sauces, Dressings and } \\
\text { Condiments }\end{array}$ & NA & NA & NA & 1.4 & 1.4 & 1.4 \\
\hline Organic Rice, Pasta and Noodles & 0.9 & 0.9 & 1.1 & 1.2 & 1.2 & 1.3 \\
\hline Organic Spreads & 1 & 1 & 1.2 & 1.2 & 1.3 & 1.4 \\
\hline Organic Sweet and Savory Snacks & 0.2 & 0.2 & 0.2 & 0.3 & 0.3 & 0.3 \\
\hline Organic Packaged Food & 9.6 & 10.3 & 12.05 & 14.4 & 15.5 & 16.7 \\
\hline
\end{tabular}

Source: Euromonitor

There are optimistic future prospects for higher sales of more processed organic products that build on the already popular basic organic products. For example, the dairy category is likely to have more sales of dairy desserts or ice cream in addition to established yogurt and cheese; pastry is likely to be added to pastries. Diversity becomes extremely important and suppliers are likely to offer new products.

The top five organic food companies accounted for $54 \%$ of sales in 2015. The market is fragmented and the remaining players are small companies with less than $1 \%$ market share. This is not favorable for demand as there is no price competition on the market and higher prices are maintained.

International manufacturers have a very strong market presence, at least $36 \%$ in 2015 according to Euromonitor and about $60 \%$ according to other sources. This is due to the fact that local suppliers are often unable to produce sufficient quantities and the quality of the products does not meet consumer requirements, which prevents them from building brands, entering retail channels and expanding their business. Another reason is that customers tend to trust foreign certified 
organic products more often than domestic ones.

Bulgarian organic products are cheaper than imported equivalents and it is likely that the increasing pricing of products will change the pricing model. The most popular local environmental brands are: Harmonica (Organic Bulgaria, organic dairy products), Gimel (fresh vegetables), Roobar (cookies / snacks), Sunny (organic baby foods, Gerada GM (honey, nuts, apricot seeds) and Bioprogram (tea and herbs). The EU and the US are the main markets for Bulgarian exports of organic products. Often local bio products enter the US market as ingredients of products produced in other EU countries. In the last two years, efforts have been made to promote exports to new markets such as Canada, China, Japan, Vietnam and Korea.

The Bulgarian export of organic roses, lavender and essential oils is traditional and commonly intended for the EU. Total exports of essential oils (HS \# 3301) in 2015 reached \$ 62 million with major destinations France and the United States. Exports of rose oil in 2015 (HS \# 330129) are reported at \$ 54 million, mainly for France and the United States. In 2014, Bulgaria completed the registration of Bulgarian Rose Oil as a Protected Geographical Indication, a process that took 10 years. In 2015, three companies were audited and certified for production and marketing of products.

Bulgaria produces around 200-250 tonnes of lavender oil (source: Inteli Agro survey Lavender, 2016) and almost all of it is exported. Lavender oil is mainly used in the distillation of rose oil products, but has recently become a leading product and has seen steady growth in local and foreign investment in these industries. In 2016, an American company invests in a large distillery in Dobrich, which is just one of many foreign direct investments in the sector. In 2015, exports of lavender oil were at a record high of 125 tonnes (valued at USD 11 million), mainly to France, the USA and Germany. The production of organic herbs (about 270 types) is annually between 15,000 tons and 17,000 tons, of which 2000 - 3000 tons are sold in Bulgaria and the rest are exported. The herbs are exported dried, mainly to Germany and Spain.

Exports of honey (conventional and organic) in 2015 are reported at levels of 9,780 tonnes (worth \$ 36 million), and all organic honey (2,000 tonnes) is exported to the EU, Japan and the USA.

Imported organic products are more competitive and dominate with a market share in excess of $60 \%$. Most of the imported products originate in Austria, Germany, Italy, Greece and the Netherlands. Currently, imported bio products have better marketing, availability and choice for local consumers. Bulgarian consumers are more likely to believe in the authenticity of certification of foreign products than national ones, which also gives them a competitive advantage in the market. Most imported brands only offer organic products. Some internationally recognized brands have offered bio versions of their traditional products on the Bulgarian market.

\section{CONCLUSION}

Most organic crops are exported due to lack of sufficient local demand and / or lack of local processors. However, due to improved consumer demand and the supply of processed products, exports of organic products fell from $90 \%-95 \%$ of total production in the past (2012-2014) to $80 \%$ in $2015 / 2016$. The local industry calls on the public administration to launch a national strategy that places greater emphasis on promoting exports of organic value-added products rather than raw materials in order to increase the competitiveness of the sector.

The main obstacle to exports is the lack of proper marketing. Organic producers are small companies and lack adequate forms of integration, which hinders their direct access to the national market. Ongoing promotional activities are not always successful. Organic grain production and organic grape production report high levels of local demand for bakery products (and / or forage in organic livestock farms) and wine, as well as favorable export opportunities; therefore, the development of these two categories is sustaining.

The best prospects are for exporting organic honey, fresh vegetables, nuts, some fruits and aromatic oils, herbs and spices. Bulgaria is currently the market leader in the production and export of aromatic, medicinal and culinary plants.

\section{REFERENCES}

1. Ordinance No. 4 of February 24, 2015, on the implementation of Measure 11 "Organic 
Agriculture" of the RDP for the period 2014-2020.

2. MAF Organic Agriculture Development in Bulgaria, Report, 2014

3. Kostadinova, P., Vl.Popov, 2012, Basic Principles and Methods of Organic Farming, Sp. New Knowledge, year 1, issue 3, ed. VUARR, Plovdiv, p.58

4. Krasteva, Il., 2014, State and tendencies for the development of organic production in Bulgaria for the period 2006-2012, Coll. . Tsenov Svishtov, p.179

5. Mitova, D., 2014, Organic production - a priority of Bulgarian agriculture in the new programming period 2014-2020, Sp., Economy and Management of Agriculture, Issue 3, IAI, Sofia, p.4-7

6. COUNCIL REGULATION (EC) N: 2092/91 on organic production of African and indication referring there to agricultural products and foodstuffs. Official Journal of the European Communities No L 189 / $1,20 . \quad 7.2007$. http://europa.eu/scadplus/leg/en/lvb/

7. Balieva, G. N., M. Huliyan (2015). Production and supply of regional food products - incentives and challenges for small holdings in Bulgaria. International
Journal of Science and Research, Online ISSN 2319-7064, Volume 4, Issue 2 February 2015, 576-580. (Available at: http://www.ijsr.net/archive/v4i2/v4i2_01.ph p\#sthash.ablyMD1V.dpbs)

8. Eurostat: Farm Structure Survey data (holdings, la-bour use, age and sex of farm managers, education and vocational training):

http://epp.eurostat.ec.europa.eu/portal/page/ portal/statistics / search_database V / Eurostat: data on the organic sector (area, crop and animal products, operators): http: //epp.eurostat.ec.europa. eu / portal / page / portal / statistics / search_database

9. FiBL and IFOAM, 2015, The World of Organic Agriculture, Statistics and Emerging Trends, https://www.fibl.org/fileadmin/documents/s hop/1663-organic-world-2015.pdf

10.Gonzalvez, V., 0. Schmid, H.WiIIer.2011. Organic Action Plans in Europe in 2011. In: Wilier, H. and Kilcher, L. eds.

11.Euromonitor, 2018, http://www.euromonitor.com/organicpackaged-food-in-bulgaria/report

12.Eurostat Database 